\title{
Comparison between a serum creatinine- and a cystatin C-based glomerular filtration rate equation in patients receiving amphotericin B
}

\author{
Iman Karimzadeh ${ }^{1}$ and Hossein Khalili ${ }^{2 *}$
}

\begin{abstract}
Serum cystatin C (Cys C) has a number of advantages over serum creatinine in the evaluation of kidney function. Apart from Cys $\mathrm{C}$ level itself, several formulas have also been introduced in different clinical settings for the estimation of glomerular filtration rate (GFR) based upon serum Cys C level. The aim of the present study was to compare a serum Cys C-based equation with Cockcroft-Gault serum creatinine-based formula, both used in the calculation of GFR, in patients receiving amphotericin B. Fifty four adult patients with no history of acute or chronic kidney injury having been planned to receive conventional amphotericin $B$ for an anticipated duration of at least 1 week for any indication were recruited. At three time points during amphotericin B treatment, including days 0,7 , and 14 , serum cystatin $C$ as well as creatinine levels were measured. GFR at the above time points was estimated by both creatinine (Cockcroft-Gault) and serum Cys $C$ based equations. There was significant correlation between creatinine-based and Cys C-based GFR values at days $0(R=0.606, P=0.001)$ and $7(R=0.714, P<0.001)$. In contrast to GFR estimated by the Cockcroft-Gault equation, the mean (95\% confidence interval) Cys C-based GFR values at different studied time points were comparable within as well as between patients with and without amphotericin B nephrotoxicity. Our results suggested that the Gentian Cys C-based GFR equation correlated significantly with the Cockcroft-Gault formula at least at the early time period of treatment with amphotericin B.
\end{abstract}

Keywords: Serum cystatin C, Serum creatinine, Glomerular filtration rate, Amphotericin B

\section{Introduction}

Serum cystatin C (Cys C), a $13 \mathrm{kDa}$ non-glycosylated protein with cysteine protease inhibitor activity, has been proposed as an alternative marker to creatinine for assessing kidney function [1]. It lacks a number of serum creatinine drawbacks such as being influenced by nonrenal factors including age, gender, muscle mass, and physical activity $[2,3]$. Dose adjustment of many medications such as antibacterials depends on patients' glomerular filtration rate (GFR). Direct measurement of GFR, using urinary inulin clearance and the plasma ${ }^{99 \mathrm{~m}}$ Tc-DTPA or ${ }^{125}$-iothalamate is cumbersome, costly, and not readily available [4].

\footnotetext{
*Correspondence: khalilih@tums.ac.ir

${ }^{2}$ Department of Clinical Pharmacy, Faculty of Pharmacy, Tehran University of Medical Sciences, Enghelab Ave, Tehran, Iran

Full list of author information is available at the end of the article
}

Besides Cys $\mathrm{C}$ level itself, different formulas have also been introduced in different clinical settings such as kidney transplant recipients [5], critically ill patients [6], chronic kidney disease [7], newborns [8], and the elderly [9] for the estimation of GFR, based upon Cys C serum level. In contrast to Cockcroft-Gault (CG) and Modification of Diet in Renal Disease (MDRD) formulas, which need several variables such as age and sex for calculation, Cys C-based equations are mainly dependent only on serum Cys $C$ levels [10]. To best of our knowledge, these equations have not been investigated well enough in drug-induced acute kidney injury (AKI) conditions. The aim of the present preliminary study was to compare a serum Cys C-based equation with the classic and prominent CG serum creatinine-based formula, both used for the calculation of GFR, in patients receiving amphotericin B (AmB). 


\section{Methods}

The data of this study was extracted from a multicentre randomized, double-blinded, placebo-controlled, clinical trial (ID: IRCT201107233449N8) that assessed the effectiveness of oral N-acetylcysteine (NAC) co-treatment with $\mathrm{AmB}$ in preventing major features of AmB nephrotoxicity [11]. Carried out in a 15-months period, from early August 2012 to November 2013, at three university health-care settings affiliated to Tehran University of Medical Sciences, Tehran, Iran, the study included 54 adult individuals with no documented history of AKI or chronic kidney disease, having been planned to receive conventional AmB for an anticipated duration of at least 1 week for any indication. They were given either placebo or $600 \mathrm{mg}$ oral NAC twice daily during the treatment course of AmB. The institutional review boards and the medical ethics committees of all hospitals approved the study and all patients or their family members signed and approved a written informed consent form.

At days 0,7 , and 14 of AmB treatment, serum Cys $C$ as well as creatinine levels were measured. Serum creatinine level was determined by an Auto-analyzer (Biotechnica BT-3000, Italy) based on the modified Jaffe colorimetric reaction. Serum Cys $C$ level was measured by the turbidimetric method (Gentian, Moss, Norway). GFR at days 0,7 , and 14 was calculated by the CG formula $[(140-$ age $) \times($ Body weight $) \times(0.85$ if female $) /($ serum creatinine $\times 72)$ ] [12]. CG values were adjusted by body surface area of relevant patients and reported as $\mathrm{ml} / \mathrm{min} / 1.73 \mathrm{~m}^{2}$. Besides CG, GFR at the above time points was also estimated by the serum Cys $\mathrm{C}$-based equation, provided in the package insert of Gentian assay kit (79.901/Serum Cys $\left.C^{1.4389}\right)$ [13]. AmB nephrotoxicity was defined by either a $50 \%$ or more decline in the estimated GFR according to the CG formula or the doubling of serum creatinine from the baseline values [14].

\section{Statistical analyses}

The possible correlation between creatinine-based and Cys C-based GFR values at days 0, 7, and 14 were assessed by the Pearson correlation test. Comparison of the mean values (95\% confidence interval $[\mathrm{CI}]$ ) of calculated creatinine-based as well as Cys C-based GFR at the above time points within and between patients with and without $\mathrm{AmB}$ nephrotoxicity was done by the one-way analysis of variance (ANOVA) with repeated measures. $P$ values $<0.05$ were considered statistically significant. Statistical analyses were carried out by the SPSS (Statistical Package for the Social Sciences) version 20 software.

\section{Results}

Among 54 patients randomly allocated into either placebo or NAC receiving group, 23 (42.59 \%) developed AmB nephrotoxicity. The mean \pm standard deviation creatinine-based GFR values at days 0,7 , and 14 were $92.94 \pm 42.04,92.21 \pm 45.92$, and $54.29 \pm 20.63 \mathrm{ml} / \mathrm{min} /$ $1.73 \mathrm{~m}^{2}$, respectively. The Cys C-based GFR value was $73.66 \pm 34.24 \mathrm{ml} / \mathrm{min} / 1.73 \mathrm{~m}^{2}$ at day $0,78.19 \pm 41.37 \mathrm{ml} /$ $\mathrm{min} / 1.73 \mathrm{~m}^{2}$ at day 7 , and $58.36 \pm 25.76 \mathrm{ml} / \mathrm{min} / 1.73 \mathrm{~m}^{2}$ at day 14.

As depicted in Fig. 1, there was significant correlation between creatinine-based and Cys C-based GFR values at days $0(R=0.606, P=0.001)$ and $7(R=0.714, P<0.001)$. In contrast, the correlation of these values at day 14 was not statistically significant $(R=0.496, P<0.071)$.

According to results of ANOVA with repeated measure analysis (Table 1 \& Fig. 2), the mean (95\% CI) creatininebased GFR at day 14 was significantly lower than that day 7 in patients who developed $\mathrm{AmB}$ nephrotoxicity $(P=0.024)$. Furthermore, the mean $(95 \% \mathrm{CI})$ decrease in creatinine-based GFR values at day 14 compared to day $0\left(-50.457[-89.477\right.$ to- 11.437$\left.] \mathrm{ml} / \mathrm{min} / 1.73 \mathrm{~m}^{2}\right)$ as well as day 14 versus day $7(-37.857$ [-63.514 to-12.2] $\mathrm{ml} / \mathrm{min} / 1.73 \mathrm{~m}^{2}$ ), were statistically significant between individuals with and without $\mathrm{AmB}$ nephrotoxicity $(P=0.016$ and $P=0.007$, respectively). In contrast to creatininebased calculated GFR, the mean (95\% CI) Cys C-based GFR values at different studied time points were comparable within as well as between patients with and without AmB nephrotoxicity.

\section{Discussion}

Although studied extensively, Cys C-based GFR equations have not generally been introduced into routine clinical practice yet. Considerable heterogeneity between relevant GFR equations can be partially taken into account for this matter [15]. Substantial heterogeneity between Cys Cbased GFR equations can be in turn attributed to four major factors including: (1) study population differences, (2) different gold standard methods of GFR measurements, (3) lack of international standardized calibration for measurement of Cys C, and (4) variation in exploited analytical techniques as well as reagents [10]. Regarding the first factor involved, elevated body mass index (BMI) can be associated with an increase in the Cys $\mathrm{C}$ concentration by about $10 \%$. Furthermore, serum Cys C concentrations have been reported to be lower in females than males (about $9 \%$ ) [15]. In the present study, no gold standard method was used for determining GFR because of both financial and technical problems.

Regarding the last two factors, three major techniques including particle-enhanced nephelometric assay (PENIA), particle enhanced turbidimetric assay (PETIA), and enzyme-linked immunosorbent assay (ELISA) are commonly used for determining Cys C. A meta-analysis on 46 articles published until December 31, 2001, revealed that immunonephelometric methods of Cys C assay produced significantly greater correlations with GFR 

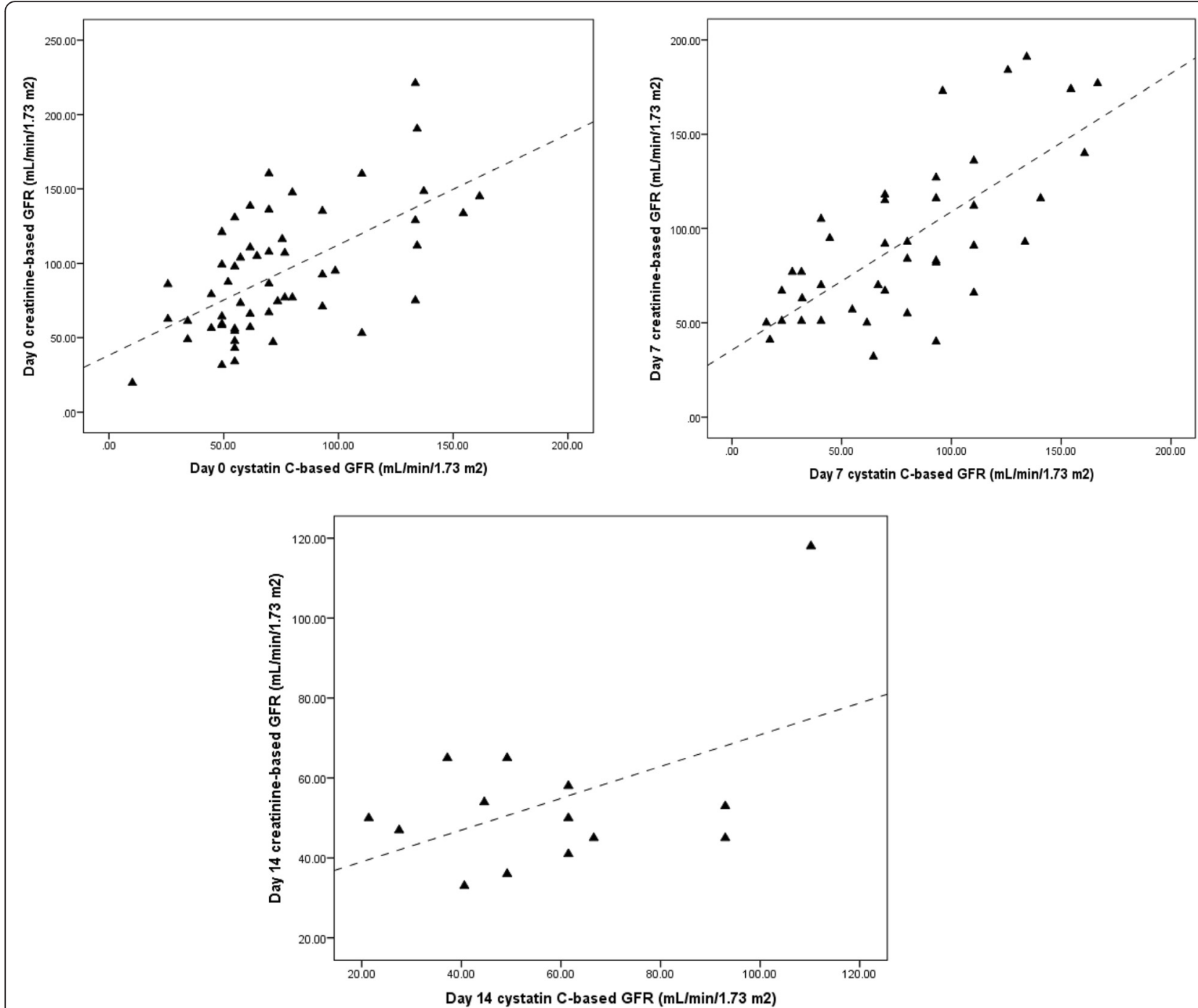

Fig. 1 The possible correlation between serum creatinine-and serum cystatin C-based GFR values at days 0, 7, 14 of amphotericin B treatment

than other assay methods $(r=0.846$ versus $r=0.784$, respectively; $P<0.001$ ) [16]. In a study on 80 healthy volunteers and 20 patients with renal and/or heart disease, the mean difference between ELISA and PETIA or ELISA and PENIA was $0.65 \pm 0.63 \mu \mathrm{g} / \mathrm{ml}$ and $0.58 \pm 0.53 \mu \mathrm{g} / \mathrm{ml}$, respectively [17]. Interestingly, Tidman et al. demonstrated that serum Cys C concentrations obtained by the Gentian method were approximately $10 \%$ lower than the DAKO method within the normal GFR range. They also reported that among Cys C-based GFR formulas examined in 644 patients, the former Orebrocyst Gentian equation (100/serum Cys C-14) had the highest accuracy [10].

The Cys C-based GFR equation used in our study was derived from Flodin et al. investigation on 160 patient samples aged above 15 years. Linear regression analysis showed that there was strong correlation between Gentian Cys C assay using a chemistry instrument (Architect ci8200) and iohexol clearance $\left(R^{2}=0.956\right)$ [18]. Lack of significant correlation between creatinine-based and Cys C-based GFR values only at day 14 but not days 0 and 7 of $A m B$ treatment in our cohort, may be due to the limited number of patients (only 16) that remained in the study at this time point. It is noteworthy that considering only correlation coefficient in our survey seems inadequate and precision, accuracy, and relative difference should also be calculated to compare these two formulas properly. The pattern of Cys C-based GFR values decreased continuously during the study in patients with $\mathrm{AmB}$ nephrotoxicity; but these changes were not statistically significant in contrast to creatinine-based GFR values. This may be justified by the limited number of serum Cys $\mathrm{C}$ level measurements at 
Table 1 Mean (95\% confidence interval) changes of creatinine-and serum cystatin C-based GFR values at days 0, 7 and 14 of amphotericin B treatment within and between patients with and without AmB nephrotoxicity

\begin{tabular}{|c|c|c|c|}
\hline Time point & Day 7 vs. Day 0 & Day 14 vs. Day 0 & Day 14 vs. Day 7 \\
\hline \multicolumn{4}{|l|}{ Creatinine-based GFR $\left(\mathrm{ml} / \mathrm{min} / 1.73 \mathrm{~m}^{2}\right)$} \\
\hline $\begin{array}{l}\text { Mean (95\% confidence interval) difference values in patients } \\
\text { with nephrotoxicity }[P \text { value] }\end{array}$ & $-6.258(-82.997$ to 70.480$)[1]$ & $-66.401(-150.289$ to 17.487$)[0.122]$ & $-60.143(-110.816$ to-9.470) [0.024] \\
\hline $\begin{array}{l}\text { Mean ( } 95 \% \text { confidence interval) difference values in patients } \\
\text { without nephrotoxicity [P value] }\end{array}$ & $-18.942(-70.939$ to 33.055$)[0.829]$ & $-34.514(-177.143$ to 48.116$)[0.656]$ & $-15.571(-74.111$ to 42.968$)[1]$ \\
\hline $\begin{array}{l}\text { Mean ( } 95 \% \text { confidence interval) difference values between } \\
\text { two groups [ } P \text { value] }\end{array}$ & $-12.6(-43.318$ to 18.118$)[0.389]$ & $-50.457(-89.477$ to- 11.437$)[0.016]$ & $-37.857(-63.514$ to-12.2) [0.007] \\
\hline \multicolumn{4}{|l|}{ Cystatin C-based GFR (ml/min/1.73 $\left.\mathrm{m}^{2}\right)$} \\
\hline $\begin{array}{l}\text { Mean ( } 95 \% \text { confidence interval) difference values in patients } \\
\text { with nephrotoxicity [P value] }\end{array}$ & $-4.3(-108.050$ to 99.45$)[1]$ & $-42.943(-103.840$ to 17.954$)[0.179]$ & $-38.643(-96.965$ to 19.679$)$ [0.217] \\
\hline $\begin{array}{l}\text { Mean ( } 95 \% \text { confidence interval) difference values in patients } \\
\text { without nephrotoxicity [P value] }\end{array}$ & $-19.357(-59.401$ to 20.686$)[0.489]$ & $-9.729(-56.979$ to 37.521$)[1]$ & $9.629(-48.990$ to 68.247$)[1]$ \\
\hline $\begin{array}{l}\text { Mean ( } 95 \% \text { confidence interval) difference values between } \\
\text { two groups [ } P \text { value] }\end{array}$ & $-11.829(-48.682$ to 25.024$)[0.498]$ & $-26.336(-51.878$ to -0.793$)[0.44]$ & $-14.507(-41.909$ to 12.895$)[0.271]$ \\
\hline
\end{tabular}



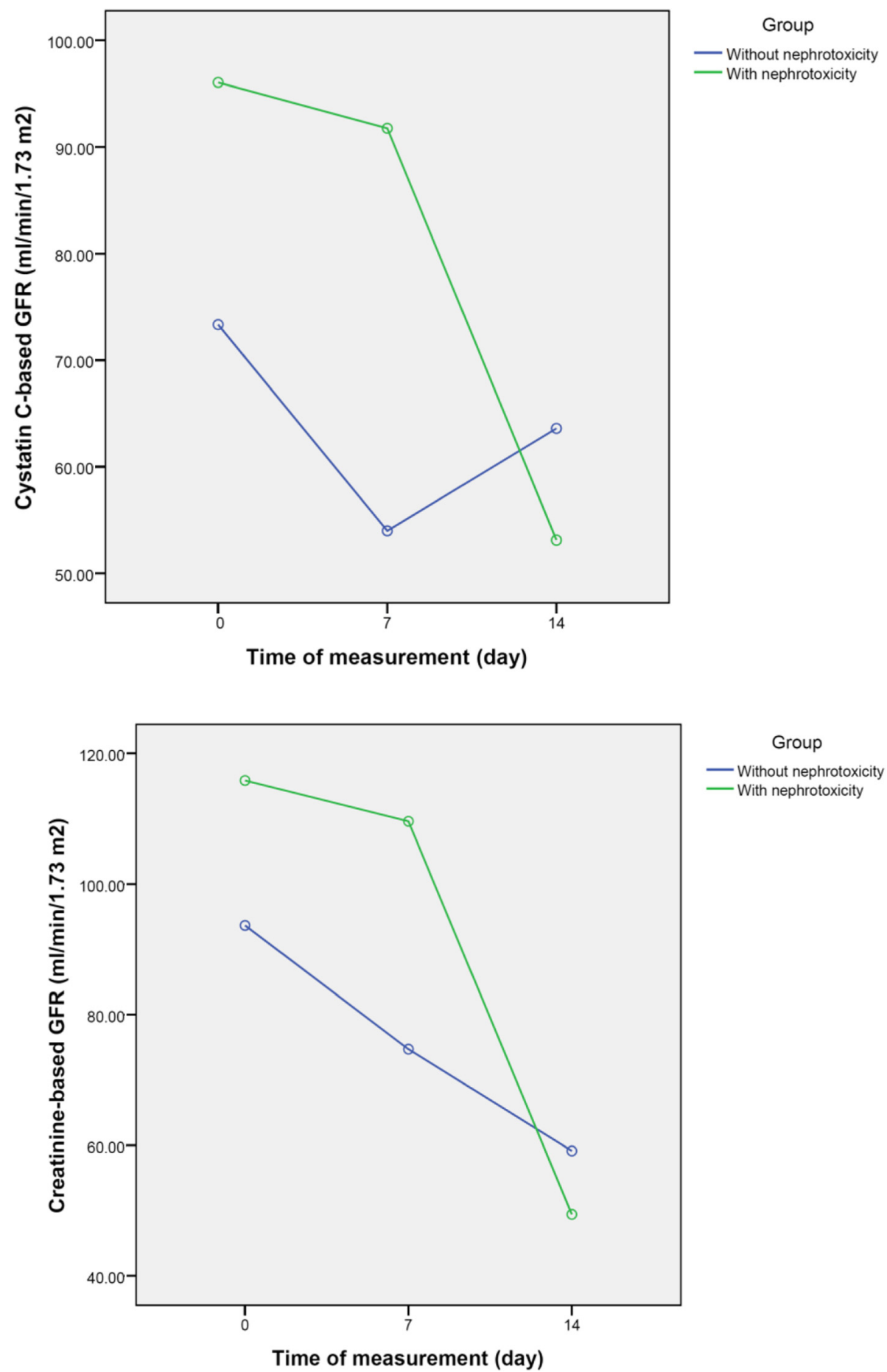

Group

only three time points during $\mathrm{AmB}$ treatment, high intraindividual variability of serum Cys $\mathrm{C}$, and absence of a gold standard method for measuring GFR.

In conclusion, our preliminary findings suggested that the Gentian Cys C-based GFR calculation equation correlated significantly with CG formula at least at the early time period of $\mathrm{AmB}$ treatment. However, the continuous decreasing trend in the mean $(95 \% \mathrm{CI})$ values of Cys C-based GFR at the studied time points was not statistically significant in patients who developed AmB 
nephrotoxicity. Measuring serum Cys $\mathrm{C}$ level at more frequent and closer time points and exploiting a gold standard method for measuring GFR can be considered for future studies in the comparison of serum Cys Cbased equations with serum creatinine-based formulas used for the calculation of GFR in patients receiving nephrotoxic medications such as AmB.

\section{Competing interests}

The authors declare no conflict of interest.

\section{Authors' contributions}

IK participated in data collection, patient sampling, performing immunoassays, statistical analyses, and manuscript drafting. HK participated in study design, interperting data, and manuscript review. Both authors (IK \& HK) read and approved the final manuscript.

\section{Author details}

${ }^{1}$ Department of Clinical Pharmacy, Faculty of Pharmacy, Shiraz University of Medical Sciences, Shiraz, Iran. ${ }^{2}$ Department of Clinical Pharmacy, Faculty of Pharmacy, Tehran University of Medical Sciences, Enghelab Ave, Tehran, Iran.

Received: 28 February 2016 Accepted: 31 March 2016

Published online: 06 June 2016

\section{References}

1. Grubb AO. Cystatin C,-properties and use as diagnostic marker. Adv Clin Chem. 2000;35:63-99.

2. Filler G, Bokenkamp A, Hofmann W, Le Bricon T, Martinez-Bru C, Grubb A. Cystatin $C$ as a marker of GFR-history, indications, and future research. Clin Biochem. 2005:38:1-8.

3. Royakkers AA, Van Suijlen JD, Hofstra LS, Kuiper MA, Bouman CS, Spronk PE, et al. Serum cystatin C-A useful endogenous marker of renal function in intensive care unit patients at risk for or with acute renal failure? Curr Med Chem. 2007;14:23147.

4. Hoste EA, Damen J, Vanholder RC, Lameire NH, Delanghe JR, Van den Hauwe K, Colardyn FA. Assessment of renal function in recently admitted critically ill patients with normal serum creatinine. Nephrol Dial Transplant. 2005:20:747-53.

5. Zahran A, Qureshi M, Shoker A. Comparison between creatinine and cystatin C-based GFR equations in renal transplantation. Nephrol Dial Transplant. 2007;22:2659-68.

6. Steinke T, Moritz S, Beck S, Gnewuch C, Kees MG. Estimation of creatinine clearance using plasma creatinine or cystatin C: a secondary analysis of two pharmacokinetic studies in surgical ICU patients. BMC Anesthesiol. 2015;15:62.

7. Bevc S, Hojs R, Ekart R, Završnik M, Gorenjak M, Puklavec L. Simple cystatin C formula for estimation of glomerular filtration rate in overweight patients with diabetes mellitus type 2 and chronic kidney disease. Exp Diabetes Res. 2012;2012:179849.

8. Treiber M, Pečovnik Balon B, Gorenjak M. A new serum cystatin C formula for estimating glomerular filtration rate in newborns. Pediatr Nephrol. 2015; 30:1297-305.

9. Ye X, Wei L, Pei X, Zhu B, Wu J, Zhao W. Application of creatinine-and/or cystatin C-based glomerular filtration rate estimation equations in elderly Chinese. Clin Interv Aging. 2014;9:1539-49.

10. Tidman M, Sjöström P, Jones I. A Comparison of GFR estimating formulae based upon s-cystatin C and s-creatinine and a combination of the two. Nephrol Dial Transplant. 2008;23:154-60.

11. Karimzadeh I, Khalili H, Sagheb MM, Farsaei S. A double-blinded, placebocontrolled, multicenter clinical trial of $\mathrm{N}$-acetylcysteine for preventing amphotericin B-induced nephrotoxicity. Expert Opin Drug Metab Toxicol. 2015;11:1345-55.

12. Cockcroft DW, Gault MH. Prediction of creatinine clearance from serum creatinine. Nephron. 1976;16:31-41.

13. Package Insert for in vitro diagnostic use only Cystatin C Immunoassay. Available from: http://gentian.no/wp-content/uploads/2013/07/PI-AssayCysC-AU-systems-v01-Jan13-.pdf

14. Goldman RD, Koren G. Amphotericin B nephrotoxicity in children. J Pediat Hematol Oncol. 2004;26:421-6.
15. Harman G, Akbari A, Hiremath S, White CA, Ramsay T, Kokolo MB, Craig J, Knoll GA. Accuracy of cystatin C-based estimates of glomerular filtration rate in kidney transplant recipients: a systematic review. Nephrol Dial Transplant. 2013:28:741-57.

16. Dharnidharka VR, Kwon C, Stevens G. Serum cystatin C is superior to serum creatinine as a marker of kidney function: a meta-analysis. Am J Kidney Dis. 2002;40:221-6.

17. Hossain MA, Emara M, El Moselhi H, Shoker A. Comparing measures of cystatin C in human sera by three methods. Am J Nephrol. 2009;29:381-91.

18. Flodin M, Jonsson AS, Hansson LO, Danielsson LA, Larsson A. Evaluation of Gentian cystatin C reagent on Abbott Ci8200 and calculation of glomerular filtration rate expressed in $\mathrm{mL} / \mathrm{min} / 1.73 \mathrm{~m}$ (2) from the cystatin $C$ values in mg/L. Scand J Clin Lab Invest. 2007;67:560-7.
Submit your next manuscript to BioMed Central and we will help you at every step:

- We accept pre-submission inquiries

- Our selector tool helps you to find the most relevant journal

- We provide round the clock customer support

- Convenient online submission

- Thorough peer review

- Inclusion in PubMed and all major indexing services

- Maximum visibility for your research

Submit your manuscript at www.biomedcentral.com/submit 